\title{
"The Drama of the Tua Line", a Fictional Narrative and Literary Dialogue With the Contemporary Portuguese Railway Technology
}

\author{
Maria Otília Pereira Lage \\ CITCEM - FLUP, Porto-Portugal
}

\begin{abstract}
This paper is a socio-literary approach to the book «TUA»COLECTÂNEA LITERÁRIA: Memórias do Vale e da Linha Férrea, a collection of literary texts on the Tua centenarian railway, like the Swiss or French Alps railways, highlighting the analysis of the short story "The Tua Line drama" which builds a fictional dialogue between objects of a technological museum about the past and the future of the Tua railway, which is now disabled. It aims to focus on and discuss relations between technology and literature within its contemporary social context and to understand their complex and dynamic interrelations of interest regarding musealization. This paper will discuss the source base, methods and theory. The source base consists of literary publications appearing throughout the twentieth century. These texts, with originate from various authors, both classic and anonymous (novels, poetry, short stories, popular literature, news columns), illustrate the action of/in the history of individuals and populations in relation to the Tua Valley, River, line and train, over the course of more than 100 years. Narratives, characters, events and episodes in various timeframes make up the set of literary fictions that provide an approximate and sensitive vision of the Tua Valley and realities around the construction, operation and closing of the railway line. Memories, identities, and historical contexts where norms, customs and social representations operate under various logics or social worlds which illustrate, by means of the fictional production of an imaginary realism, the socio-historical meaning of the Tua Valley and line. The methods employed are a longitudinal qualitative analysis of the occurrence of these themes during this period, and a socio-historical content analysis, drawing from literary studies, which aims to identify the main patterns of fictional narrative, in which sociotechnical knowledge regarding railways was packaged. The interdisciplinary analysis which is made is developed in the socio-historical framework (M. Block), the "sociology of action" (Thévenot \& Boltanski), the theory of social representations (Durkheim) and literature theory (Todorov) and aims to open other avenues of academic research on this topic.
\end{abstract}

Keywords: fictional narrative and musealization, memory of Tua railways, railroad history and literature on the Tua Line

Unpublished text of the paper presented to International Committee for the History of Technology Technology, Innovation, and Sustainability: Historical and Contemporary Narratives.43rd ICOHTEC meeting. Sub-theme: Displaying the past or teaching the future? In quest for sustainable museum of technology.

Maria Otília Pereira Lage, Ph.D. in Contemporary History, Historian and Integrated researcher at the CITCEM-FLUP (Oporto - Portugal). 


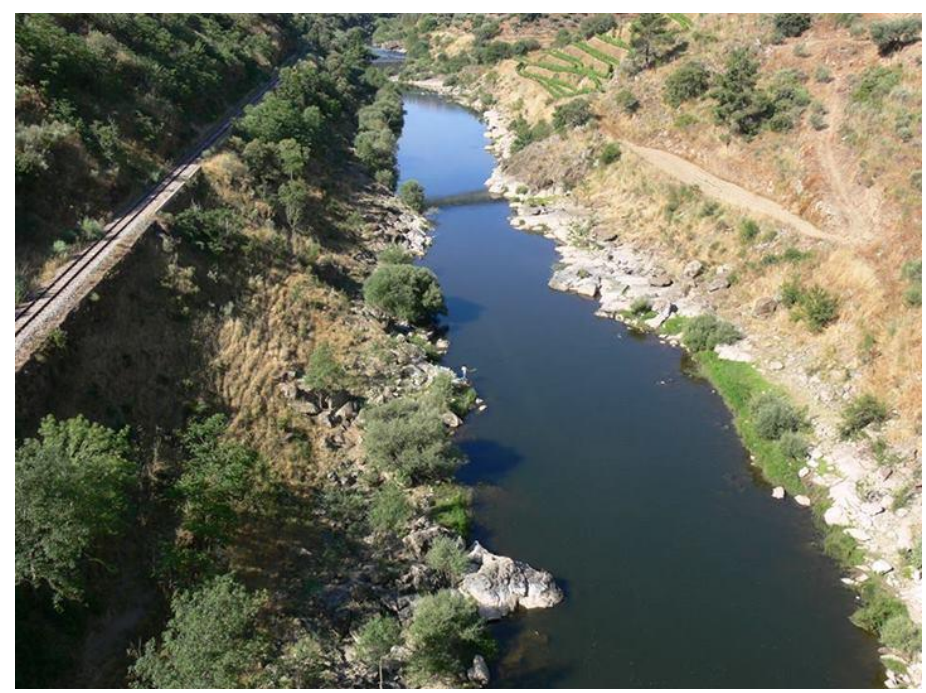

The Tua River and the Line.

\section{Introduction}

This paper is an approach to the subject of literary fiction and technology from the short story "The drama of the Tua Line...", of which the author is a Portuguese emigrant in France, and holds the pseudonym António Cravo. It is a fictional dialogue between human objects (railway staff) and non-human (rolling stock versus espolio Railway Museum) of the Tua Line. This story is included (pp. 162-175) in the work LAGE, Otilia, Eduardo Beira (1st ed. 2012, 2nd ed. 2014) “Tua' Literary Collection: the valley, the river and the railway line"1 and its analysis, developed on the border of literature and technology, allows for the discussion of the theme of the symposium "Displaying the past or teaching the future? In the quest for sustainable museum of technology", highly topical and relevant.

\section{An Approach to "'Tua' Literary Collection: The Valley, the River and the Railway Line"}

This work is a book of memories, historical, social representations and literary impressions, which in the form of hypertext brings together 45 authors from the nineteenth century to the end of the twentieth century. These selected texts come from various literary genres (novels, poetry, short story, popular literature, etc.) providing access to knowledge which crisscrosses science, technology, education, art and culture, in one social and literary space configuration susceptible in the museum area of the centennial railroad in northern Portugal. Such is the central argument of "The drama of the Tua line: Mr. Manuel 'Moreno' last rail of the 'district", the tale chosen for particular analysis.

Art and Technology: from Walter Benjamin's concept of "Technical Reproducibility"2 to the proposal of the virtual museum, it was the transformative array of editorial organization "of "Tua' Literary Collection..." which leads to noting the documentary and artistic functions of photography, and relates them to the notions of technical reproducibility and mechanical reproduction approached by W. Benjamin.

\footnotetext{
1 This book occurred within the context of the FOZTUA Project (2001-2004), a joint interdisciplinary project between MIT (USA) and University of Minho (Portugal), sponsored by EDP and under the auspices of the MIT Portugal Program. The projects aims to study, preserve and disseminate the memory of the Tua valley and its historically significant narrow gauge railroad.

2 BENJAMIN, Walter (1994), "A obra de arte na era de sua reprodutibilidade técnica", in BENJAMIN, Walter, Magia e Técnica,

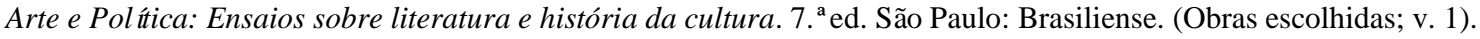




\section{Hypertext Narrative}

This hypertext narrative or "hiperficción" combines photography and literary text, and as such, readers build their own ways, temporal sequences and "jumps" as their informational requirements. The hypertext structure consists of "us" or "lexias", information units containing different data types such as text, graphics, photos, sounds, animated sequences, information codes, applications, etc. These lexias necessarily are connected by links to a number of other composite structures also by "lexias". Each of these can be viewed by one or more windows on the computer screen.

This was the way chosen to organize this literary collection of the "Tua" valley and the railway line.

\section{Social Representations in "Tua' Literary Collection..."}

The Tua train whistle that, with the clank of its carriages on the tracks, pierces the silence of the valley, the narrow railroad that runs in echoes through the granitic slopes, Transmontano country, the space traversed by the locomotive coal and steam, a symbol that the industrial revolution came, late and incomplete, appears as a strong image of "progress, development and communication." It organizes the possible readings of this collection, refocusing the voices around the nuclear social representation of the rail path, the first major machine which churned north-eastern delay sediment, shifting their ancestral notions of space, time and speed.

The bars of iron machine, moving and/or still in uncharted stations and tiny halts, bringing about new and successive configurations of space-time, people and goods in transit not only by its induced transformations but also seeing past the train. The opening of the Tua centennial railway line and the circulation of the train were attracting businesses and markets, passengers, visitors, and curious, bringing news from the world's most remote places, revolutionizing slowly but decisively confined everyday, producing new memories and causing other perceptions.

This is a first and crucial set of social representations, transversal to all literary fictions of this "Tua" Literary Collection, around which gravitate other social representations for which, in its spatio-temporal dimension, as an element of fiction [Aguiar and Silva (1974)], it continues.

The explosions of dynamite, the engineering of buildings, as the employment of modern techniques in the opening of the new road bridge at the mouth of the river Tua, a whole historic landscape in which the imposing nature coexists strangely with the technique.

The literary fragments that make up the analyzed collection, united in its diversity by a common theme of the Tua Valley - the opening of the railroad, its operation for more than a century and the closing of the line-perceived and reinvented in multiple "logics" or "social worlds", build as an epic collective crossed by different signs of a vaunted progress and regional development. 


\section{Logics or Social Worlds: Another Perspective of Analysis}

Table 1

Social Worlds or Social Logics

\begin{tabular}{|c|c|c|c|c|}
\hline Domestic logic & Industrial logic & Market logic & Inspiration logic & Civic logic \\
\hline $\begin{array}{l}\text { Estates and the absent } \\
\text { farm owner }\end{array}$ & $\begin{array}{l}\text { The train as the iron } \\
\text { horse and beautiful iron } \\
\text { monster }\end{array}$ & $\begin{array}{l}\text { Train and railway, means } \\
\text { and connection route }\end{array}$ & Literary fictions & $\begin{array}{l}\text { Denunciation of the line's } \\
\text { closure and the "night of } \\
\text { theft" of the engines }\end{array}$ \\
\hline $\begin{array}{l}\text { Agriculture in the Tua } \\
\text { Valley, toil of } \\
\text { agricultural land } \\
\end{array}$ & $\begin{array}{l}\text { Construction of the Tua } \\
\text { line }\end{array}$ & $\begin{array}{l}\text { Transportation of people } \\
\text { and goods }\end{array}$ & Poetic writing & $\begin{array}{l}\text { Defense of a world of values } \\
\text { and of natural and historical } \\
\text { heritage }\end{array}$ \\
\hline $\begin{array}{l}\text { Relation between railway } \\
\text { and local populations. }\end{array}$ & Railway workers & $\begin{array}{l}\text { Controversial debates } \\
\text { around the opening of the } \\
\text { line }\end{array}$ & Norms and customs & $\begin{array}{l}\text { Abandoned stops and closed } \\
\text { stations }\end{array}$ \\
\hline $\begin{array}{l}\text { Local rural practices, } \\
\text { uses and customs } \\
\end{array}$ & $\begin{array}{l}\text { Whistle of the train and } \\
\text { the noise of the rails }\end{array}$ & Mobility and emigration & Literary plots & $\begin{array}{l}\text { Controversy surrounding the } \\
\text { construction of the dam }\end{array}$ \\
\hline River ferries & $\begin{array}{l}\text { Steam engine, } \\
\text { locomotives, handles, } \\
\text { levers }\end{array}$ & $\begin{array}{l}\text { Transportation of } \\
\text { agricultural products and } \\
\text { goods }\end{array}$ & \begin{tabular}{|l} 
Erudite and \\
mythological \\
perceptions
\end{tabular} & $\begin{array}{l}\text { Uproar and social revolt } \\
\text { Scuffles }\end{array}$ \\
\hline \begin{tabular}{|l} 
Hospitality of local \\
populations and \\
socialization
\end{tabular} & $\begin{array}{l}\text { Idea of progress and } \\
\text { regional development }\end{array}$ & $\begin{array}{l}\text { English Port wine } \\
\text { merchants }\end{array}$ & $\begin{array}{l}\text { Diachronic } \\
\text { perception of time }\end{array}$ & $\begin{array}{l}\text { Official opening of the line, } \\
\text { construction and progress of } \\
\text { a region. }\end{array}$ \\
\hline $\begin{array}{l}\text { Beliefs and superstitions } \\
\text { (the devil...) }\end{array}$ & $\begin{array}{l}\text { Explosive force of } \\
\text { dynamite }\end{array}$ & $\begin{array}{l}\text { Highly competitive } \\
\text { environment of wine and } \\
\text { spirits }\end{array}$ & $\begin{array}{l}\text { Mountains' open } \\
\text { arms. } \\
\text { Womb of strange } \\
\text { fragrances }\end{array}$ & $\begin{array}{l}\text { Right to the continuity of life } \\
\text { of the Tua Valley populations }\end{array}$ \\
\hline
\end{tabular}

This theoretical coordination framework was built to face problems and questions deriving from the plural use of the micro and macro scales and the necessity of integration between action and structure. It allows us to approach this regional case and other national or international cases at an interpretative and explanatory level.

\section{"The Drama of the Tua Line: Mr. Manuel 'Moreno' Last Rail of the 'District"'/António Cravo}

This short literary story is a multi-perspective discursive construction of the literary memory of the centenarian Tua Line and train. It is an anthropomorphized demonstration of the railway world at a socio-cultural, "natural", technical, and historical level, and as a spatio-temporally anchored object.

The author, born in a village of the Tua Valley but residing in Paris for many years, is a journalist, associative, writer and sociologist who obtained with this short story an honorable mention in the competition held in the centennial celebrations of the Tua Line in 1988, a quite significant year, and can show us, through experiences marked into society, the purpose of the operation, maintenance and closure of this railway.

"The drama of the Tua line..." is a short narrative (p. 9) which tells, dialogically, the socio-history of the construction, operation, technical maintenance and closure of the Tua line, through a dialogue between human objects (railway staff of the track and train, passengers) and non-human objects (locomotives, trolleys, rails, sleepers, wheels, screws, pails of zinc, coal machine and diesel engine trains, goods produced and transported between transmontana region and major cities).

All these literary characters cross the countryside into the socio-technical world of this railway and live together in a shed which has been transformed into a railway museum, where they exist as discarded tools in disuse, old machinery and rolling stock, transformed into museum objects which highlights the functional role of the fast centennial train. 
In this metaphorically-built setting takes place, in simultaneously technical and poetic language, a friendly and didactic conversation between two old friends, a trolley and a locomotive, who go about commenting on stations and stops, tunnels and bridges, track work and the motion of the Tua Line, while seeing very few visitors of the virtual museum.

The ideological universe in which the story is built is the social denunciation of the closure of the railway line - harbinger of future public polemic regarding the end to the operation of the Tua train-which is attributed to the greed of so-called "auditing men."

In a socio-historical perspective the author denounces the neo-liberal political decisions to dismantle this narrow gauge line to the detriment of the interests and needs of local populations and the region which, for a century, were served by the train, and counteracts this economic situation of abandonment and social impoverishment, recovery, museum preservation and processing of railway technical infrastructure.

\section{Configurations: Literature, Technology and Railway Museums}

"The drama of the Tua Line ..."-An allegory of a train ride and representation of a virtual railway museum - requires a more comprehensive analysis, as literary works and documentary corpus which allow one intuit the intersection of literary, technological and museological settings.

The museum supports today's current discussion of the virtual world and the difficulty that museums in the contemporary world face to change the "place of memory" which is now attributed to them.

It raises the issue of the relationship between museums and science: museums as scientific knowledge production sites and scientific research as a basic function of museums. In the past, science was clearly linked to museums, which only later became associated with the protection of places of old things and exhibitions.

This work suggests thinking the railway museum along the lines of museums of science and technology with a holistic view of movable cultural property, sites and monuments.

This work opens for discussion the multiple temporalities present in a museum, the relational issues between information, communication and education and the use of digital media, in the shape of support resources banking increasingly on interactive learning.

As such, one must also equate the four types of internet-based concepts of museum which Schweibenz (2004) establishes: Brochure Museum, which is in fact a common web page that provides the information that belongs to the museum (e.g. opening hours, exhibitions, etc.); Content Museum, which concentrates the museum's information, through the use of little textbooks, and is aimed at experts; Learning Museum, which, similarly to the former, but to a non-expert general public; Virtual Museum, whose presentation is exclusively this digital internet-based medium.

Accordingly, this work suggests as necessary the articulation of these four internet-defined types of museum (Schweibenz, 2004): Brochure Museum, Content Museum, Learning Museum and Virtual Museum as much-recommended dimensions in the field of modern museology, as they are consistent with the relevance of the sub-theme of this symposium "Displaying the past or teaching the future? In quest for sustainable museum of technology".

\section{Analytical Framework}

Events and episodes in various time spaces make up the set of literary fictions which provide an approximate and sensitive vision of the Tua Valley and the realities around the construction, operation and 
closing of the railway line. Memories, identities, historical contexts where norms, customs and social representations operate under various logics or social worlds which illustrate, through the fictional production of an imaginary realism, the socio-historical meaning of the Tua line and train, throughout over 100 years.

Therefore, the methodology used was necessarily a longitudinal qualitative analysis of the occurrence of these themes during the twentieth century, and a socio-historical content analysis, drawing from literary studies, which aims to identify the main patterns of fictional narrative, in which sociotechnical knowledge about "railway" was packaged.

The interdisciplinary approach made is grounded on the socio-historical framework (M. Block), the "sociology of action" (Thévenot and Boltanski), the theory of social representations (Durkheim) and literature theory (Todorov), and aims to open other avenues of academic research on this topic.

\section{Final Considerations}

Through the aforementioned and analytical interest of literary writing produced around a socio-technical universe, such as this rail world, this work has permitted us to reveal the important role that literary text can play with regards to knowledge of the socio-history of science and techniques in relation to its context and environment.

These different representations, within logical or identified social worlds, illustrate the potentially pedagogical and didactic function of literature in the field of musealization sites and technological infrastructure.

This case study shows the multiple interrelations that can be established between literature and technology, contributing in this way to foresee rail museums within the scope of the emerging educational paradigm and a consistent and focused education for the future.

\section{References}

BLOCH, M. (1997). Apologie pour l'histoire ou Métier d'historien. Paris: Masson, Armand Colin.

BOLTANSKI, L., \& THÉVENOT, L. (1991). De la justification: Les economies de la grandeur. Paris: Gallimard.

BURKE, P. 2009. Afterword. In SORLIN, S. and WARDE, P., Org. (2009), Natures' send: History and the environment. Houndmills: Palgrave Macmillan.

DELEUZE, Gilles e GUATTARI, Félix. 1992. O que é a filosofia? Lisboa: Editorial Presença.

DOMINGUES, Álvaro. (2014). “Fotografalar do Tua”. Prefácio a «TUA»Colectânea Literária: Vale, Rio, Linha e Comboio. $2^{\mathrm{a}}$ ed. Foz Tua: FOZTUA Project; EDP; MIT Portugal. pp. V-X.

DURKHEIM, É. (1970). La science sociale et l'action. Paris, PUF.

FONSECA, Luís Adão da. (2004). As relações entre História e Literatura no contexto da actual crise da dimensão social da narrativa historiográfica. Actas do Colóquio Internacional Literatura e História. Porto, 1, 265-278.

LAGE, Maria Otilia Pereira, \& LAGE, Jorge, M. B. (2005). "Saber Sever": Geios de Escrita e História. Estudos \& Documentos. Douro, 19, 237-262.

LAGE, Maria Otilia Pereira, \& BEIRA, E. (2013). "Tua” Colectânea Literária: Vale, Rio, Linha e Comboio. Foz Tua: FOZTUA Project, .EDP, MIT Portugal.

LATOUR, Bruno. (2004). Politics of nature: How to bring the sciences into democracy. Harvard University Press.

LE ROY LADURIE, E. (1974). Présentation. Annales - Économies, Societés, Civilisations, 29(3).

MATURANA, H. R., \& VARELA, F. G. (1987). The tree of knowledge. Shambhala, Boston.

POMIAN, K. (1999). Surl'histoire. Paris: Gallimard.

PRIGOGINE, I., \& STENGERS, I. (1985). Order out of chaos: Man's new dialogue with Nature. London: Flamingo.

RHEINBERGER, H.-J. (2013). Itérations. Paris: Diaphanes.

SILVA, Vítor Manuel de Aguiar e. (1974). O texto literário e os seus códigos. Revista Colóquio/Letras. Ensaio, 21, 23-33. 
THÉVENOT, L. (1983). L'économie du codage social. Critiques de l'économie politique, 23-24, 188-222. TODOROV, T. (2008). Teoria da literatura II. Lisboa: Edições 70.

WORSTER, D. (1991). Para fazer história ambiental. Estudos Históricos. Rio de Janeiro. 4(8), 198-215. 